\title{
ANALISIS TINGKAT KEPATUHAN MASYARAKAT DALAM MEMBAYAR PAJAK BUMI DAN BANGUNAN (PBB) (STUDI KASUS DESA LONAM KABUPATEN SAMBAS)
}

\author{
Eko Febri Lusiono, Suharman \\ Prodi Akuntansi Keuangan Perusahaan \\ Politeknik Negeri Sambas \\ Email: ekodelisa2004@gmail.com
}

\begin{abstract}
This research entitled "Analysis of Community Compliance Level in Paying Land and Building Taxes (UN) Case Study of Lonam Village District of Sambas Regency" is a fundamental research considering that the transition of UN status which was originally a central tax has now become a regional tax. UN acceptance is very instrumental in regional development. The object in this study is the United Nations taxpayer and government officials who are authorized to collect the United Nations tax. The purpose of this research is to find out the community's compliance in paying land and building tax as an effort to increase the regional income in Lonam village. factors that influence community compliance in paying Land and Building Taxes as an effort to increase Regional Income in Lonam village, Subdistrict subdistrict. The research method used qualitative research, which is a research process that produces descriptive data the form of written or oral information obtained from the research object. This research is expected to be a benchmark for the government, whether taxpayers have complied with paying the UN and whether the community already knows the rules that are set because this research can be used as supporting media in the implementation of government regulations, especially the Regional Regulation. Sambas Number 6 of 2012 concerning Land and Rural and Urban Buildings Taxes.
\end{abstract}

Keywords: Pajak Bumi dan Bangunan (PBB)

\section{PENDAHULUAN}

Undang-Undang Nomor 28, Pasal 1 Ayat (1) tahun 2007 menyebutkan bahwa pajak merupakan kontribusi wajib kepada negara yang terutang oleh pribadi atau badan yang bersifat memaksa berdasarkan undang-undang, dengan tidak mendapat imbalan secara langsung dan digunakan untuk keperluan negara bagi kemakmuran rakyat. Peranan penerimaan pajak menjadi sangat dominan dalam menunjang jalannya pemerintahan dan pembangunan nasional karena pajak yang dipungut negara akan digunakan kembali untuk kesejahteraan rakyat dan membiayai aktifita pemerintahan negara dan daerah.

Pajak terdiri dari pajak pusat dan pajak daerah. Pajak pusat merupakan pajak yang pemungutan dan pengelolaannya dilakukan oleh pemerintah pusat. Sedangkan pajak daerah adalah adalah pajak yang dikelola oleh bupati atau walikota yang kemudian dilimpahkan kepada pemerintah kecamatan sebagai kepala wilayah dengan melibatkan seluruh perangkat desa atau kelurahan serta instansi lainnya sebagai pembantu dan pelaksanaan pemungutan pajak. Salah satu pajak daerah adalah Pajak Bumi dan Bangunan atau disingkat PBB. 
Pajak Bumi dan Bangunan (PBB) adalah Pajak Negara yang dikenakan terhadap bumi dan atau bangunan berdasarkan Undang-undang nomor 12 Tahun 1985 tentang Pajak Bumi dan Bangunan sebagaimana telah diubah dengan Undang-Undang nomor 12 Tahun 1994. Sedangkan Undang-undang Nomor 28 Tahun 2009 Tentang Pajak Daerah dan Retribusi Daerah menyebutkan bahwa PBB perdesaan dan perkotaan merupakan pajak daerah yang menjadi kewenangan pemerintah kabupaten/kota. PBB adalah pajak yang bersifat kebendaan dalam arti besarnya pajak terutang ditentukan oleh keadaan objek yaitu bumi/tanah dan atau bangunan. Keadaan subjek (siapa yang membayar) tidak ikut menentukan besarnya pajak.

Kabuapaten Sambas adalah salah satu pemerintah daerah kabupaten yang memiliki wewenang untuk memungut PBB sebagai upaya untuk menambah pembiayaan aktifitas pemerintahan. Salah satunya untuk menambah pembiayaan pembangunan daerah. Kabupaten Sambas memiliki 19 kecamatan yaitu Selakau, Selakau Timur, Salatiga, Pemangkat, Semparuk, Tebas, Sebawi, Sambas, Jawai, Subah, Sajad, Sajingan, Teluk Keramat, Paloh, Jawai, Jawai Selatan, Tekarang, Galing, Sejangkung, dan Tangaran. Pada tahun 2017 kecamatan Pemangkat adalah salah satu kecamatan yang memperoleh pendapatan PBB paling besar setelah kecamatan sambas yaitu sebesar Rp411.291.751. Kecamatan Pemangkat terdiri dari delapan desa dengan rincian pendapatan PBB pada tabel berikut:

Tabel 1.1

Rincian ketetapan pokok pendapatan PBB dan Realisasinya di Kec. Pemangkat Tahun 2017

Sumber: BKD Kab Sambas 2017

Berdasarkan tabel 1.1 dapat dilihat bahwa desa Lonam mempunyai SPPT paling banyak yaitu sejumlah 2.303 SPPT dengan

\begin{tabular}{|c|c|c|c|c|c|c|c|c|c|}
\hline \multirow[b]{2}{*}{$\begin{array}{l}\mathbf{N} \\
\mathbf{0}\end{array}$} & \multirow[b]{2}{*}{ Desa } & \multicolumn{2}{|c|}{ Ketetapan Tahun } & \multicolumn{3}{|c|}{$\begin{array}{l}\text { Realisasi Ketetapan } \\
\text { Tahun } 2017\end{array}$} & \multicolumn{3}{|c|}{ Selisih } \\
\hline & & SPPT & $\begin{array}{c}\text { Jlh } \\
\text { (dlm } \\
\text { jutaan } \\
\text { ) }\end{array}$ & SPPT & $\begin{array}{c}\text { Jlh } \\
\text { (dlm } \\
\text { jutaan } \\
\text { ) }\end{array}$ & $\%$ & SPPT & $\begin{array}{c}\text { Jlh } \\
\text { (dlm } \\
\text { jutaan } \\
\text { ) }\end{array}$ & $\%$ \\
\hline & $\begin{array}{l}\text { Perapa } \\
\text { kan }\end{array}$ & 257 & 13,2 & 152 & 7,1 & $\begin{array}{l}54, \\
3\end{array}$ & 105 & 6,0 & 45,7 \\
\hline 1 & $\begin{array}{l}\text { Jelutun } \\
\mathrm{g}\end{array}$ & 1558 & 37,2 & 979 & 24,3 & $\begin{array}{l}65, \\
4\end{array}$ & 579 & 12,9 & 34,6 \\
\hline 2 & $\begin{array}{l}\text { Harapa } \\
\mathrm{n}\end{array}$ & 1198 & 53,4 & 706 & 27,1 & $\begin{array}{l}50, \\
7\end{array}$ & 492 & 26,3 & 49,3 \\
\hline 3 & $\begin{array}{l}\text { Penjaj } \\
\text { ap }\end{array}$ & 2262 & $\begin{array}{l}79,5 \\
\end{array}$ & 1224 & 43,6 & $\begin{array}{l}54, \\
8\end{array}$ & 1038 & 36,0 & 45,2 \\
\hline 4 & $\begin{array}{l}\text { Peman } \\
\text { gkat }\end{array}$ & 2190 & 273,3 & 1414 & 189,7 & $\begin{array}{l}69, \\
4 \\
\end{array}$ & 776 & 83,6 & 30,6 \\
\hline 5 & $\begin{array}{l}\text { Sebatu } \\
\text { an }\end{array}$ & 929 & 79,1 & 372 & 20,5 & $\begin{array}{l}26, \\
0\end{array}$ & 557 & 58,5 & 74,0 \\
\hline 6 & Lonam & 2303 & 143,3 & 845 & 57,6 & $\begin{array}{l}40, \\
2\end{array}$ & 1458 & 85,7 & 59,8 \\
\hline 7 & $\begin{array}{l}\text { G. } \\
\text { Sejaht } \\
\text { era }\end{array}$ & 1163 & 78,0 & 469 & 41,1 & $\begin{array}{l}51, \\
4\end{array}$ & 694 & 38,9 & 48,6 \\
\hline \multicolumn{2}{|c|}{ Jumlah } & 11860 & 759,3 & 6161 & 411,3 & $\begin{array}{l}54, \\
2\end{array}$ & 5.699 & 347.9 & 45,8 \\
\hline
\end{tabular}

ketetapan senilai Rp143.335.261,-. Namun realisasinya kurang dari $50 \%$ yaitu hanya sebesar $40.2 \%$. Sebagai desa yang mempunyai SPPT paling banyak seharusnya desa Lonam juga menerima pendapatan yang paling banyak. Dengan adanya hal tersebut peneliti tertarik untuk melakukan penelitian tentang "Analisis Tingkat Kepatuhan Masyarakat dalam Membayar Pajak Bumi dan Bangunan (PBB) Studi Kasus Desa Lonam Kecamatan Pemangkat Kabupaten Sambas".

\section{TELAAH LITERATUR}

\subsection{Pajak}

\subsubsection{Pengertian Pajak}

Pajak adalah pungutan wajib yang dibayar rakyat untuk negara dan digunakan untuk kepentingan pemerintah dan masyarakat umum. Rakyat yang membayar pajak tidak merasakan manfaat dari pajak secara langsung, karena pajak digunakan untuk kepentingan umum, bukan untuk kepentingan pribadi. Pajak merupakan salah satu sumber pendapatan pemerintah untuk melakukan pembangunan, baik pemerintah pusat maupun pemerintah daerah. Pemungutan pajak dapat dipaksakan karena dilaksanakan berdasarkan undangundang. 
Berdasarkan UU KUP NOMOR 28 TAHUN 2007, pasal 1, ayat 1, pengertian Pajak adalah kontribusi wajib kepada negara yang terutang oleh orang pribadi atau badan yang bersifat memaksa berdasarkan undangundang, dengan tidak mendapatkan imbalan secara langsung dan digunakan untuk keperluan negara bagi sebesar-besarnya kemakmuran rakyat.

\subsubsection{Karakteristik Pajak}

1. Pajak Merupakan Kontribusi Wajib Warga Negara

Artinya setiap orang memiliki kewajiban untuk membayar pajak. Namun hal tersebut hanya berlaku untuk warga negara yang sudah memenuhi syarat subjektif dan syarat objektif. Yaitu warga negara yang memiliki Penghasilan Tidak Kena Pajak (PTKP) lebih dari Rp2.050.000 per bulan. Jika Anda adalah karyawan/pegawai, baik karyawan swasta maupun pegawai pemerintah, dengan total penghasilan lebih dari Rp2 juta, maka wajib membayar pajak. Jika Anda adalah wirausaha, maka setiap penghasilan dikenakan pajak sebesar $1 \%$ dari total penghasilan kotor/bruto (berdasarkan PP 46 tahun 2013).

2. Pajak Bersifat Memaksa Untuk Setiap Warga Negara

Jika seseorang sudah memenuhi syarat subjektif dan syarat objektif, maka wajib untuk membayar pajak. Undangundang pajak sudah menjelaskan, jika seseorang dengan sengaja tidak membayar pajak yang seharusnya dibayarkan, maka ada ancaman sanksi administratif maupun hukuman secara pidana.

3. Warga Negara Tidak Mendapat Imbalan Langsung

Pajak berbeda dengan retribusi. Contoh retribusi: ketika mendapat manfaat parkir, maka harus membayar sejumlah uang, yaitu retribusi parkir, namun pajak tidak seperti itu. Pajak merupakan salah satu sarana pemerataan pendapatan warga negara. Jadi ketika membayar pajak dalam jumlah tertentu, anda tidak langsung menerima manfaat pajak yang dibayar, yang anda dapatkan berupa perbaikan jalan raya di daerah anda, fasilitas kesehatan gratis bagi keluarga, beasiswa pendidikan bagi anak anda, dan lain-lainnya.

4. Berdasarkan Undang-undang

Artinya pajak diatur dalam undangundang negara. Ada beberapa undangundang yang mengatur tentang mekanisme perhitungan, pembayaran, dan pelaporan pajak.

\subsubsection{Fungsi Pajak bagi Negara dan Masyarakat}

Pajak memiliki peranan yang signifikan dalam kehidupan bernegara, khususnya pembangunan. Pajak merupakan sumber pendapatan negara dalam membiayai seluruh pengeluaran yang dibutuhkan, termasuk pengeluaran untuk pembangunan. Sehingga pajak mempunyai beberapa fungsi, antara lain:

1. Fungsi Anggaran (Fungsi Budgeter)

Pajak merupakan sumber pemasukan keuangan negara dengan metode mengumpulkan uang dari wajib pajak ke kas negara untuk membiayai pembangunan nasional atau pengeluaran negara lainnya. Sehingga fungsi pajak merupakan sumber pendapatan negara yang memiliki tujuan menyeimbangkan pengeluaran negara dengan pendapatan negara.

2. Fungsi Mengatur (Fungsi Regulasi)

Pajak merupakan alat untuk melaksanakan atau mengatur kebijakan negara dalam lapangan sosial dan ekonomi. Fungsi mengatur tersebut antara lain:

1) Pajak dapat digunakan untuk menghambat laju inflasi. 
2) Pajak dapat digunakan sebagai alat untuk mendorong kegiatan ekspor, seperti: pajak ekspor barang.

3) Pajak dapat memberikan proteksi atau perlindungan terhadap barang produksi dari dalam negeri, contohnya: Pajak Pertambahan Nilai (PPN)

4) Pajak dapat mengatur dan menarik investasi modal yang membantu perekonomian agar semakin produktif.

3. Fungsi Pemerataan (Pajak Distribusi)

Pajak dapat digunakan untuk menyesuaikan dan menyeimbangkan antara pembagian pendapatan dengan kebahagiaan dan kesejahteraan masyarakat.

4. Fungsi Stabilisasi

Pajak dapat digunakan untuk menstabilkan kondisi dan keadaan perekonomian, seperti: untuk mengatasi inflasi, pemerintah menetapkan pajak yang tinggi, sehingga jumlah uang yang beredar dapat dikurangi. Sedangkan untuk mengatasi kelesuan ekonomi atau deflasi, pemerintah menurunkan pajak, sehingga jumlah uang yang beredar dapat ditambah dan deflasi dapat di atasi.

\subsection{Pajak Bumi dan Bangunan (PBB)}

PBB adalah pajak yang bersifat kebendaan dalam arti besarnya pajak terutang ditentukan oleh keadaan objek yaitu bumi dan atau bangunan. Keadaan subjek tidak ikut menentukan besarnya pajak. PBB pada awalnya merupakan pajak pusat yang alokasi penerimaannya dialokasikan ke daerah-daerah dengan proporsi tertentu, namun demikian dalam perkembangannya berdasarkan Undang-Undang No. 28 Tahun 2009 tentang PDRD pajak ini khususnya sector perkotaan dan pedesaan menjadi sepenuhnya pajak daerah.

\subsubsection{Pengertian dan Dasar hukum PBB}

PBB dikenakan terhadap objek pajak berupa tanah dan atau bangunan yang didasarkan pada asas kenikmatan dan manfaat, dan dibayar setiap tahun. PBB pengenaannya didasarkan pada Undangundang No. 12 tahun 1985 tentang Pajak Bumi dan Bangunan sebagaimana telah diubah dengan undang-undang nomor 12 tahun 1994. Namun demikian dalam perkembangannya PBB sektor pedesaan dan perkotaan menjadi pajak daerah yang diatur dalam undang-undang nomor 28 tahun 2009 tentang Pajak Daerah dan Retribusi Daerah (PDRD) Pasal 77 sampai dengan Pasal 84 mulai tahun 2010.

Ketentuan Umum yang memberikan penjelasaan tentang istilah-istilah teknis atau definisi-definisi PBB seperti pengertian:

1) Bumi adalah permukaan bumi dan tubuh bumi yang ada dibawahnya. Pengertian ini berarti bukan hanya tanah permukaan bumi saja tetapi betul-betul tubuh bumi dari permukaan sampai dengan magma, hasil tambang, gas material yang lainnya.

2) Bangunan adalah konstruksi teknik yang ditanam atau dilekatkan secara tetap pada tanah dan/atau perairan.

Dalam pasal 77 ayat (2) UndangUndang PDRD, disebutkan bahwa termasuk dalam pengertian bangunan adalah:

a. Jalan lingkungan yang terletak dalam suatu kompleks bangunan seperti hotel, pabrik, dan emplasemennya dan lain-lain yang satu kesatuan dengan kompleks bangunan tersebut,

b. Jalan TOL,

c. Kolam renang,

d. Pagar mewah,

e. Tempat olah raga,

f. Galangan kapal, dermaga,

g. Taman mewah,

h. Tempat penampungan/kilang minyak, air dan gas, pipa minyak, 
i. Fasilitas lain yang memberikan manfaat.

\subsubsection{Objek PBB}

Objek PBB adalah bumi dan/atau bangunan, dimana pengertian bumi dan/atau bangunan adalah sebagai berikut:

Bumi adalah permukaan bumi yang meliputi tanah dan perairan pedalaman serta laut wilayah Indonesia, dan tubuh bumi yang ada di bawahnya. Bangunan, adalah kontruksi teknik yang di tanam atau di lekatkan secara tetap pada tanah dan/atau perairan.

Tidak semua objek bumi dan bangunan dikenakan PBB, ada juga objek yang di kecualikan dari pengenaan PBB adalah apabila sebagai berikut:

1) Digunakan semata-mata untuk melayani kepentingan umum di bidang ibadah, sosial, kesehatan, pendidikan dan kebudayaan nasional, yang tidak dimaksud-kan untuk memperoleh keuntungan,

2) Digunakan untuk kuburan, peninggalan purbakala, atau yang sejenis dengan itu,

3) Merupakan hutan lindung, hutan suaka alam, hutan wisata, taman nasional, tanah penggembalaan yang dikuasai oleh desa, dan tanah negara yang belum di bebani suatu hak,

4) Digunakan oleh perwakilan diplomatik, konsulat berdasarkan asas perlakuan timbal balik,

5) Digunakan oleh badan atau perwakilan organisasi internasional yang ditentukan oleh Menteri Keuangan.

Objek pajak yang digunakan oleh negara untuk penyelenggaraan pemerintahan, penentuan pengenaan pajaknya diatur lebih lanjut dengan Peraturan Pemerintah.

\subsubsection{Subjek PBB}

Subjek PBB adalah orang atau badan yang secara nyata mempunyai suatu hak atas bumi, dan / atau memperoleh manfaat atas bumi, dan / atau memiliki, menguasai, dan / atau memperoleh manfaat atas bangunan. Melihat pengertian subjek pajak tersebut, tidak jarang ada objek pajak yang diakui oleh lebih dari satu orang subjek pajak, yang berarti ada satu objek pajak tetapi memiliki beberapa wajib pajak.

\subsubsection{Penilaian}

PBB yang dibayarkan oleh wajib pajak (WP) tergantung pada nilainya. Penilaian objek PBB pedesaan dan perkotaan meliputi penilaian objek tanah dan bangunan yang dilakukan oleh Ditjen Pajak (pemerintah daerah menurut UU No. 28 Tahun 2009) untuk menentukan NJOP yang dijadikan sebagai dasar pengenaan pajak. Untuk menilai objek properti tersebut digunakan beberapa metode penilaian sebagai berikut:

1) Pendekatan Data Pasar (Market Data Approach).

a. NJOP dihitung dengan cara membandingkan Objek pajak yang sejenis dengan Objek lain yang telah diketahui harga pasarnya.

b. Pendekatan ini pada umumnya digunakan untuk menentukan NJOP tanah, namun dapat juga dipakai untuk menentukan NJOP bangunan.

2) Pendekatan Biaya (Cost Approach), pendekatan ini digunakan untuk menentukan nilai tanah atau bangunan terutama untuk menentukan NJOP bangunan dengan menghitung seluruh biaya yang dikeluarkan untuk membuat bangunan baru yang sejenis dikurangi dengan penyusutan phisiknya.

3) Pendekatan Pendapatan (Income Approach)

a. Pendekatan ini digunakan untuk menentukan NJOP yang tidak dapat dilakukan berdasarkan pendekatan data pasar atau pendekatan biaya, 
tetapi ditentukan berdasarkan hasil bersih objek pajak tersebut,

b. Pendekatan ini terutama digunakan untuk menentukan NJOP galian tambang atau objek perairan

\section{METODE PENELITIAN}

\subsection{Lokasi dan Waktu Penelitian}

Penelitian ini dilakukan di desa Lonam kecamatan Pemangkat kabupaten Sambas dalam waktu 4 bulan.

\subsection{Objek Penelitian dan Jenis Penelitian}

Objek penelitian merupakan sasaran, tujuan, dan kegunaan terhadap sesuatu permasalahan untuk mendapatkan jawaban atau solusi dan kemudian dapat ditarik sebuah kesimpulan. Objek dalam penelitian ini adalah wajib pajak PBB dan aparatur pemerintah yang berwenang dalam melakukan pemungutan pajak PBB. Sedangkan jenis penelitian yang digunakan adalah penelitian kualitatif, yaitu proses penelitian yang menghasilkan data deskriptif berupa informasi tertulis atau lisan yang didapat dari objek penelitian.

\subsection{Jenis dan Sumber Data}

Pada penelitian ini peneliti menggunakan data primer dan data sekunder. Data primer adalah data yang dikumpulkan langsung dari sumber data dan berhubungan langsung dengan permasalahan yang diteliti (Kuncoro, 2009:148), dalam penelitian ini data primernya berupa data yang diperoleh dari narasumber melalui wawancara. Sedangkan data sekunder adalah data yang diperoleh dari pihak lain, tidak langsung diperoleh peneliti dari subjek penelitiannya, dalam penelitian ini data sekundernya berupa data pajak dari Badan Keuangan Daerah serta studi pustaka (buku, jurnal dll).

\subsection{Teknik Pengumpulan Data}

\subsubsection{Wawancara}

Menurut Lexy J. Moleong
$(2012: 186)$ wawancara adalah teknik mendapat informasi dengan cara bertanya langsung kepada informan, percakapan dengan maksud tertentu. Percakapan itu dilakukan oleh dua pihak, yaitu pewawancara (interviewer) yang mengajukan pertanyaan dan yang ditanggapi memberikan jawaban atas pertanyaan itu. Alat wawancara yang digunakan adalah pedoman wawancara, yaitu sebuah catatan yang berisi pertanyaan-pertanyaan yang ditujukan pada narasumber selama proses penelitian berlangsung.

\subsubsection{Teknik Observasi}

Nawawi (2007:106) dalam bukunya menyebutkan bahwa observasi adalah pengamatan dan pencatatan secara sistematik terhadap gejala yang tampak pada objek penelitian, observasi langsung dilakukan terhadap objek tempat terjadi atas berlangsungnya peristiwa sehingga observer berada bersama objek yang diselidikinya. Alat yang digunakan untuk mempermudah melakukan observasi adalah catatan lapangan.

\subsubsection{Studi Kepustakaan}

Pada penelitian ini peneliti menggunakan berbagai karya tulis, buku, dan jurnal sebagai media untuk memperoleh informasi yang akan mendukung penelitian, dan media-media tersebut akan dicantumkan pada daftar pustaka salah satunya adalah data sekunder tentang penerimaan PBB tahun 2017 dari Badan Keuangan Daerah (Bakeuda) kabupaten Sambas.

\subsection{Teknik Pengolahan dan Analisis} Data

Teknik pengolahan data yang digunakan dalam penelitian ini adalah teknik triangulasi, yaitu teknik pemeriksaan keabsahan data yang memanfaatkan sesuatu yang lain di luar data itu untuk keperluan pengecekan atau pembanding terhadap data 
itu. Sedangkan teknik analisis data yang digunakan dalam penelitian ini adalah sebagai berikut:

1. Reduksi data/pemilihan data, yang bertujuan untuk penyederhanaan data.

2. Display data/penyajian data

3. Verifikasi dan penerikan kesimpulan, yaitu penarikan makna dari data yang ada dengan melibatkan pemahaman peneliti.

\section{HASIL PENELITIAN DAN PEMBAHASAN \\ 4.1. Hasil Penelitian}

Penelitian yang dilakukan penulis menggunakan data yang diperoleh dari Badan Keuangan Daerah Kabupaten Sambas dan informasi dari hasil wawancara kepada beberapa narasumber yang berdomisili di lokasi penelitian. Narusumber tersebut adalah aparatur pemerintah Desa Lonam yang banyak mengetahui tentang PBB, ketua RT yang menyampaikan informasi kepada masyarakat terkait PBB, dan beberapa orang warga selaku wajib pajak PBB.

Kepatuhan masyarakat desa Lonam dalam membayar pajak PBB dinilai berdasarkan tiga aspek yaitu, aspek yuridis,

\begin{tabular}{|c|c|c|c|c|c|c|c|c|}
\hline \multirow[t]{2}{*}{ Thn } & \multicolumn{2}{|c|}{ Ketetapan } & \multicolumn{2}{|c|}{ Realisasi } & \multirow[t]{2}{*}{$\%$} & \multicolumn{2}{|c|}{ Selisih } & \multirow[t]{2}{*}{$\%$} \\
\hline & $\begin{array}{l}\text { SP } \\
\text { PT }\end{array}$ & $\begin{array}{c}\text { Jlh } \\
\text { (dlm } \\
\text { jutaa } \\
\text { n) }\end{array}$ & $\begin{array}{l}\text { SP } \\
\text { PT }\end{array}$ & $\begin{array}{c}\text { Jlh } \\
\text { (dlm } \\
\text { jutaa } \\
\text { n) }\end{array}$ & & $\begin{array}{l}\text { SP } \\
\text { PT }\end{array}$ & $\begin{array}{c}\text { Jlh } \\
\text { (dlm } \\
\text { jutaa } \\
\text { n) }\end{array}$ & \\
\hline 2015 & $\begin{array}{l}20 \\
16\end{array}$ & 94,7 & $\begin{array}{l}71 \\
9\end{array}$ & 36,7 & 38 & $\begin{array}{l}12 \\
97\end{array}$ & 58,0 & $\begin{array}{l}61, \\
2\end{array}$ \\
\hline 2016 & $\begin{array}{l}22 \\
42\end{array}$ & $\begin{array}{l}141, \\
9\end{array}$ & $\begin{array}{l}82 \\
2\end{array}$ & 59,2 & 41 & 14 & 82,6 & $\begin{array}{l}58, \\
2\end{array}$ \\
\hline 2017 & $\begin{array}{l}23 \\
03\end{array}$ & $\begin{array}{l}143, \\
3\end{array}$ & $\begin{array}{l}84 \\
5\end{array}$ & 57,6 & 37 & $\begin{array}{l}14 \\
58\end{array}$ & 85,6 & $\begin{array}{l}59, \\
8\end{array}$ \\
\hline
\end{tabular}

aspek psikologis dan aspek sosiologis. Berikut ini potensi dan realisasi penerimaan PBB Desa Lonam (Lihat Tabel 5.1).

Tabel 5.1

Realisasi Penerimaan PBB Desa Lonam Tahun 2015-2017

Sumber: BKD Kab Sambas 2017
Berdasarkan tabel 5.1 di atas diperoleh data bahwa jumlah wajib pajak bumi dan bangunan yang terdaftar di desa Lonam pada tahun 2015 yaitu sebesar 2.016. Namun, dari jumlah wajib pajak tersebut realisasi penerimaan $\mathrm{PBB}$ hanya sebesar 719, sedangkan jumlah SPPT tidak tertagih sebesar 1.297, dari hasil tersebut diperoleh persentase kepatuhan wajib pajak bumi dan bangunan di desa Lonam kecamatan Pemangkat pada tahun 2015 adalah 38\%. Pada tahun 2016 jumlah wajib pajak bumi dan bangunan yang terdaftar di Desa Lonam Kecamatan Pemangkat yaitu sebesar 2.242. Namun, dari jumlah wajib pajak tersebut realisasi penerimaan $\mathrm{PBB}$ hanya sebesar 822. Sedangkan jumlah SPPT tidak tertagih sebesar 1.420, dari hasil tersebut diperoleh persentase kepatuhan wajib pajak bumi dan bangunan di Desa Lonam Kecamatan Pemangkat pada tahun 2016 sebesar $41 \%$. Yang terakhir pada tahun tahun 2017 jumlah wajib PBB yang terdaftar di desa Lonam kecamatan Pemangkat sebesar 2.303 dari jumlah wajib pajak tersebut realisasi penerimaan PBB hanya sebesar 845 SPPT, sedangkan jumlah SPPT tidak tertagih adalah sebesar 1.458, dari hasil tersebut diperoleh persentase kepatuhan wajib pajak bumi dan bangunan di Desa Lonam Kecamatan Pemangkat pada tahun 2017 sebesar $37 \%$.

Tabel di atas juga menunjukan bahwa terdapat selisih yang sangat besar antara ketetapan dengan realisasi penerimaan PBB di desa Lonam. Sejak tiga tahun terkahir yaitu tahun 2015 sampai dengan tahun 2017 rata-rata selisih lebih dari 50\% yaitu sebesar $59,7 \%$. Pada tahun 2015 terdapat target SPPT sebanyak 2.016 namun yang terealisasi hanya sebanyak 719 SPPT atau $38 \%$ jadi selisih antara ketetapan SPPT dengan realisasinya sebesar $38 \%$. Pada tahun 2016 terdapat target SPPT sebanyak 
2.242 yang terealisasi hanya sebanyak 822 SPPT atau $41 \%$ jadi selisih antara ketetapan SPPT dengan realisasinya sebesar 58,2\%. Sedangkan pada tahun 2017 terdapat target SPPT sebanyak 2.303 namun yang terealisasi hanya sebanyak 845 SPPT atau $37 \%$ jadi selisih antara ketetapan SPPT dengan realisasinya sebesar $59,8 \%$.

Berdasarkan hasil wawancara peneliti kepada beberapa orang perangkat desa selaku aparatur yang menangani masalah PBB kepada warga setempat rendahnya realisasi penerimaan PBB di Desa Lonam disebabkan oleh beberapa hal berikut:

\section{1) Banyaknya SPPT yang tumpang tindih}

Menurut bapak Ernedi selaku Kasi Pemerintahan Desa Lonam hal ini terjadi karena banyak masyarakat yang tanah dan bagunananya sudah terjual tetapi status PBBnya masih menggunakan nama pemilik lama, terus banyak pemilik tanah di Desa Lonam yang berada di luar daerah seperti di Pontianak, di Tebas, di Jakarta dan lain-lain atau tidak ada di tempat sehingga sulit untuk dihubungi saat pembayaran PPB, serta ada juga wajib pajak yang sudah meninggal dunia.

\section{2) Wajib Pajak Yang tidak Ada di Tempat}

Penyebab lainnya juga di sampaikan oleh bapak Solihin selaku ketua BPD desa Lonam, beliau mengatakan kalau penyebab rendahnya realisasi penerimaan $\mathrm{PBB}$ di Desa Lonam adalah wajib pajak yang tidak ada ditempat atau sudah berdomisili di daerah lain. "Wajib pajak, orangnya tidak domisili di tempat objek pajaknya, padahal letak objek pajak dengan nomor urut objek pajak ada wilayah, misalnya ada kode 14 yang ternyata kode 14 tidak ada dia, ilang nomornya/terlangakui, itu yang membuat susah dicari, karena ada orang minta carikan datanya tapi ndak dapat, terpaksa kita ke sambas lagi, sehingga dapat salinannya, setelah itu dia bayar. Data yang ada kurang akurat yang menyebabkan adanya tumpang tindih data PBB itu. Beliau menjelaskan wajib pajak tidak berdomisili di Desa Lonam.

\section{3) Banyak Masyarakat yang Belum Balik Nama atas Tanah dan Bangunan Yang Bersangkutan}

Ketika ditanyakan penyebab rendahnya kepada bapak Hairudin selaku ketua RT 02 dusun Pembangunan selaku orang yang menyampaikan informasi secara langsung kepada masyarakat tekait PBB. Berikut penyataan beliau "Karena kita sudah menyampaikan SPPT ke masyarakat, terkadang biasanya kita mencari orang yang memiliki tanah ada yang sudah meninggal tetapi namanya masih tercantum di PBB padahal sudah transaksi jual beli tanah, jadi banyak yang tanah sudah terjual tetapi masih saja PBB-nya belum balik nama, karena masih banyak kita tidak mengetahui masyarakat yang bukan mayoritas penduduknya di desa Lonam, orangnya sulit dicari, itulah kendalanya banyak penyebabnya realisasi penerimaan PBB di desa Lonam rendah".

\section{4) Kurangnya kesadaran masyarakat untuk membayar pajak PBB}

Kurangnya kesadaran masyarakat dalam membayar PBB juga menjadi salah satu penyebab rendahnya realisasi penerimaan PBB di Desa Lonam Kecamatan Pemangkat. Hal ini disampaikan langsung oleh Kasi Pemerintahan Desa Lonam "Kurangnya kesadaran masyarakat memang cukup rendah, memang pembayar pajak yang berada di desa luar tidak pernah datang untuk mengambil SPPT PBB di desa Loman , dan kita tidak tahu keberadaan orang tersebut. Mereka mengalami kesulitan untuk menghubungi wajib pajak yang berada di luar desa Lonam, sedangnkan masyarakat 
itu sendiri kkurang menyadari kewajiban mereka untuk membayar pajak

\section{5) Kurangnya Sosialisasi atau Penyuluhan Tentang Pajak Bumi dan Bangunan}

Penyuluhan atau sosialisasi terkait pemungutan PBB merupakan salah satu cara untuk meningkatkan realisasi penerimaan PBB. Desa Lonam kecamatan pemangkat merupakan desa yang paling besar jumlah SPPT PBBnya dibanding desa lainnya di seluruh kecamatan Pemangkat, namun sayangnya realisasi penerimaan $\mathrm{PBB}$ tersebut kurang dari 50\% sejak tiga tahun terakhir yaitu dari tahun 2015 sampai dengan tahun 2017. Salah satu penyebab hal tersebut adalah kurangnya peyuluhan atau sosialisasi terkait PBB yang diberikan kepada masyarakat. Hal ini disampaikan langsung oleh Kasi Pemerintahan Desa Lonam "Untuk sementare memang belum hanya memeperingatkan banwa pentingnye untok membayar pajak, hasil pemungutan pajak yang diambil dari daerah itu dampaknye untuk pembangunan daerah, cuman setakat itu sementara, pasti akan ade rencane kedepannye untok melakukan penyulohan karena dengan rendahnya partisipasi dengan berbagai kendala yakni kite tidak bise memastikan karena kendala dengan rendahnya tingkat penerimaan daerah di desa Lonam terutama untok dana PBB tinggal beberapa faktor itu tadek beberapa memang terjadi tumpang tindih dana PBB yang seharusnye nama lamak itu udah tidak ada lagi nyatanya timbul kembali dan juga desa Lonam merupakan pecahan dari desa Harapan, yang dibeberapa blok yang seharusnye terletak di desa Harapan masih berada didesa Lonam. Misalnya perbatasan dusun pembangunan dengan dusun teluk nusa desa harapan terjadi tumpang tindih.Waktu pemekaran untuk desa Lonam dimulai tahun 2015. Intinya mereka belum memberikan sosialisasi untuk meningkatkan kesadaran masyarakat, namun kedepannya mereka berencana untuk memberikan sosialisasi tersebut, apalagi dengan adanya peralihan pajak PBB yang awalnya merupakan pajak pusat sekarang menjadi pajak daerah.

Masyarakat desa Lonam menyambut baik adanya peralihan PBB dari pajak pusat menjadi pajak daerah. Hal ini disampaikan langsung oleh ketua BPD desa lonam. Beliau menyampaikan "Mudah-mudahan bagi kawan-kawan yang berperanan dalam mengurus PBB itok dapat mensosialisasikan yang betul-betul gencar untuk dapat memberikan wawasan pengetahuan tentang hal-hal tersebut, agar masyarakat sadar bahwe wajib bayar pajak meskipun sedikit. Dari pajak itok di untok membangun daerah kite. Beliau berharap kepada pihak yang mengurus pajak PBB dapat memberikan sosialisasi kepada masyarakat agar masyarakat sadar untuk membayar pajak, karena dari pendapatan pajak kita bisa membangun daerah kita. Ketika ditanyakan kepada ketua RT 2 desa Lonam, beliau menjelaskan "Saya rasa cukup baik jika pengelolaanya memang baik, memang peralihannya memang bagus, dengan beralihnya dari pusat ke daerah otomatis pendapatan daerah bertambah, walaupun dengan penambahan tersebut otomatis pembangunan daerah akan meningkat kalau penggunaan anggaran tersebut betul-betul dimanfaatkan. Beliau menyambut baik dengan adanya peralihan pajak PBB dari pajak pusat menjadi pajak daerah, dengan adanya hal tersebut tentunya akan meningkatkan pendapatan daerah dan meningkatkan pembangunan daerah kalau penggunaannya betul-betul dimanfaatkan.

Penyebab tersebut membuat peneliti ingin mengetahui bagaimana proses atau mekanisme pemungutan PBB di Desa 
Lonam Kecamatan Pemengkat dan cara untuk meningkatkan realisasi penerimaan PBB. Menurut Kasi Pemerintahan, Ketua BPD dan dua orang ketua RT pemungutan PBB diserahkan langsung kepada masyarakat, aparatur desa hanya memberikan informasi dan SPPT kepada masyarakat. Selanjutnya masyarakat yang akan membayar PBB ke Bank Pembangunan Daerah (Bank Kalbar) atau Kantor Pos. Mereka juga menjelaskan ada masyarakat yang sudah menerima SPPT tapi tidak juga membayar PBBnya.

Tiga tahun yang lalu pemerintah desa Lonam kecamatan Pemangkat menerapkan sistem jemput bola dalam pemungutan $\mathrm{PBB}$, tapi sistem tersebut tidak lagi dijalankan karena merasa khawatir jika masyarakat akan berfikir pendapatan PBB tersebut nantinya akan disalahgunakan oleh aparatur desa. Hal ini tentunya juga didukung oleh penjelasan dari salah satu warga yang di wawancarai oleh penulis. Dia menyebutkan kalau lebih baik membayar sendiri ke Bank atau Kantor Pos. Karena kalau sudah begitu kita jadi yakin bahwa kita sudah membayar pajak" jawabnya.

Sedangkan cara untuk meningkat realisasi penerimaan $\mathrm{PBB}$ adalah dengan memberikan sosialisasi kepada masyarakat sebagai upaya untuk menyampaikan pengertian, informasi, dan pembinaan wajib pajak khususnya mengenai segala sesuau yang berhubungan dengan perpajakan (Basamalah 2008:11). Wajib pajak mengetahui dan memahami peraturan perpajakan melalui sosialisasi yang peraturan pajak melalui training perpajakan yang mereka ikuti. Menurut Nurmantu (2005:67) untuk mencegah wajib pajak melakukan tindakan yang mengurangi kepatuhan atas kewajiban perpajakannya dapat dicegah dengan memberikan sosialisasi secara intensif kepada wajib pajak

\section{SIMPULAN}

\subsection{Simpulan}

Berdasarkan hasil penelitian yang telah dilakukan dapat disimpulkan bahwa kepatuhan masyarakat Desa Lonam Kecamatan Pemangkat dalam membayar Pajak Bumi dan Bangunan masih belum optimal. Hal ini dapat dilihat dari persentase realisasi penerimaan PBB Desa Lonam Kecamatan Pemangkat selama tiga tahun terakhir yaitu dari tahun 2015 sampai 2017 selalu kurang dari 50\%, pada tahun 2015 sebesar 38\%, pada tahun 2016 sebesar $41 \%$ dan pada tahun 2017 sebesar 37\%.

Penyebab rendahnya penerimaan PBB di desa Lonam kecamatan Pemangkat adalah:

1) SPPT banyak yang tumpang tindih.

2) Wajib pajak yang tidak ada di tempat atau berada di luar desa Lonam.

3) Sertifikat masyarakat belum balik nama atas nama pemilik sah tanah dan bangunan.

4) Kurangnya kesadaran masyarakat untuk membayar Pajak Bumi dan Bangunan.

5) Kurangnya sosialisasi atau penyuluhan kesadaran membayar PBB oleh pihak terkait.

\subsection{Saran}

Saran yang dapat disampaikan untuk penelitian tentang Kepatuhan Masyarakat dalam membayar Pajak Bumi dan Bangunan di Desa Lonam Kecamatan Pemangkat yang pertama adalah pemerintah terkait harus memperbaharui data SPPT agar data SPPT tidak tumpang tindih. Kedua adalah pemerintah harus meningkatkan informasi mengenai kewajiban masyarakat untuk membayar Pajak Bumi dan Bangunan melalui sosialisasi atau penyuluhan tentang PBB atau berbagai kegiatan lainnya seperti 
kegiatan keagamaan, kegiatan sosial dan lain-lain.

\section{DAFTAR PUSTAKA}

[1]Andrian, S.(2011). Hukum pajak. Jakarta: Sinar Grafika

[2]Chairil AP. (2015). Manajemen Perpajakan,: Bandung: PT. Gramedia Pustaka Utama

[3]Instruksi Presiden Republik Indonesia Nomor 3 Tahun 2003 Tentang Kebijakan dan Strategi Nasional Pengembangan E-Government

[4]Kuncoro, M.(2009). Metode Riset untuk Bisnis dan Ekonomi. Jakarta: Erlangga

[5]Mardiasmo. (2016). Perpajakan Edisi Terbaru 2016. Yogyakarta C.V Andi Offiset:

[6]Panduan PKM Dana DIPA Poltesa Edisi II (2017), Pusat Penelitian dan Pengabdian Kepada Masyarakat, Politeknik Negeri Sambas.

[7]Perda Kab. Sambas Nomor 6 Tahun 2012 Tentang Pajak Bumi dan Bangunan Perdesaan dan Perkotaan.

[8]Permendagri Nomor 113 Tentang Pedoman Pengelolaan Keuangan Daerah

[9]Puji Astuti. 2011. Tingkat Kepatuhan Masyarakat dalam Membayar Pajak Bumi dan Bangunan (PBB) di Kelurahan Serang Kecamatan Serang
Tahun 2010. Skripsi Ilmu Administrasi Negara UNTIRTA

[10]Rahmawati. 2013. "Analisis Kepatuhan Masyarakat Dalam Membayar Pajak Bumi Dan Bangunan Di Desa Ranjeng Kecamatan Ciruas Kabupaten Serang.

[11]Sugiyono, (2012). Metode Penelitian Pendidikan-Pendekatan Kuantitatif, Kualitatif, $R \& D$. Badung: Alfabeta Bandung

[12]Undang-undang nomor 12 Tahun 1985 tentang Pajak Bumi dan Bangunan

[13] Undang-Undang Nomor 12 tahun 1994 Tentang Perubahan Pertama UndangUndang Nomor 12 Tahun 1985 Tentang Pajak Bumi dan Bangunan. Jakarta.

[14]Undang-Undang Nomor 17 Tahun 2003 Tentang Keuangan Negara

[15]Undang-Undang Nomor 25 Tahun 2004 Sistem Perencanaan Pembangunan Nasional

[16]Undang-undang Nomor 28 Tahun 2009 Tentang Pajak Daerah dan Retribusi Daerah

[17]Undang-Undang Nomor 6 Tahun 2014 Tentang Desa 